\title{
The Sociological Debate of the Life Sciences Research: from Molecular Biology to Human Genome Sequencing
}

\author{
Renan Gonçalves Leonel da Silva [SILVA, R. G. L.] (Corresponding author) \\ Post-doctoral researcher, Department of Preventive Medicine, School of Medicine \\ University of São Paulo, São Paulo, Brazil \\ E-mail: leonnelrg@gmail.com \\ Maria Conceição da Costa [COSTA, M. C.] \\ Associate Professor, Department of Science and Technology Policy, Institute of \\ Geosciences, Brazil \\ University of Campinas, Campinas, Brazil
}

Received: October 21, 2016 Accepted: January 5, 2017 Published: March 17, 2017

doi:10.5296/ijssr.v5i1.10185 URL: http://dx.doi.org/10.5296/ijssr.v5i1.10185

\begin{abstract}
This paper presents some sociological debates involved in the new field of life sciences at the end of 20th century. From a bibliographic review concerning history of science and Social Studies of Science, it will be presented some particular sociological issues of the research on molecular biology and its historical evolution - the formation of speeches and legitimization; institutional arrangements and alliances in post-war period. We will focuses on the emerging systems of information and communication technology, ICTs. and how it transformed the biomedical research. The goal is to show briefly how molecular biology was built, from the post-war period to the end of the 90's, and what was the main proceedings of interdisciplinary associations and technoscientific interactions in the life sciences agenda.
\end{abstract}

Keywords: social studies of science and technology, life sciences, molecular biology, human genome sequencing

\section{Introduction}

The progress on human biotechnology has been noticed for at least three converging factors about the scientific practice in biomedical research after the 1970's: 
(a) the rising of international partnerships in science and technology and broadcast concerning life sciences, with emphasis on the cooperation between universities and medical centers in developed countries; (b) a streamlining process of biomedical research, towards database building and using of information systems for large-scale investigations and (c) the directing of medicine for human genome's knowledge and the possibilities of therapeutic interventions at the molecular level (CLARKE et al., 2003).

These movements are related to the emerging areas with future potential, as regenerative medicine, for example. The biotechnology has been allied with the scientific authority introduced by the finishing of Human Genome project, in 1999, by an international scientific collaboration consortium. This agenda brought to the center of the debate about the future of the life sciences, in which science-based treatments would evolve towards medicines' production and target-therapies at the molecular level.

Those are some of the contemporary discussions. However, which were the historical processes that guided the technology production in the life sciences' area? Certainly, these aspects refer to (at least) three factors: (a) the rise of Molecular Biology in the 1940's, (b) the alliance with epistemological authority of Physics in post-war period - Atomic age (Big Science) and (c) a convergence process with the information and communication technologies (ICTs) from the 1970's on including a rising process of computer modeling and the emerging of bioinformatics (de CADAREVIAN, 2010; STRASSER, 2009).

The paper is organized as it follows. Firstly, we will present some issues involved in the context of molecular biology's (MB) historical evolution (formation of speeches and legitimization, institutional arrangements on post-war period and connections with TIC's). The focus is to show that the evolution of DNA technologies and the globalization large-scale biological research were essential to make possible the new agenda for biomedical research on early $20^{\text {th }}$ century.

Next, the text will be identified some of the contributions by Biomedicalization studies' literature (CLARKE et al., 2003) and by part of the sociology of science and technology, about the social uniqueness of a technological artifact, turning the process of Biomedicine's Technoscientification into a crucial thing for the understanding of the scientific practice set in the area after the 1970's.

The text is concluded with an analysis of scientific convergence between ICTs and its role on the redefinition of research tools at the genomic area. Thinking about the implications of Human Genome sequencing and information technologies' role, we identify new proceedings of construction and legitimization on modern science, which point to the scientist's authority building at the $21^{\text {st }}$ century, facing specifically the molecular biology's history and its evolutionary logic in the past century.

\section{The Emergence of Molecular Biology in Post-War Period}

The researches towards the study of human genome are sustained by an historical process of scientific knowledge (re)production characteristic of MB's agenda (Note 1). This agenda became known in 1953, when the English biophysicist Francis Crick, with James Watson 
altogether, proposed the structure of the DNA molecule, whose famous "double helix model" would emerge as one of the most relevant discoveries on cellular life (STRASSER, 2002; de CADAVERIAN, 1996). It must be kept in mind that the institutional conciliation process had enabled MB's rising as one of the most dynamic scientific fields on $20^{\text {th }}$ century history.

Thereby, MB's dynamism had been related to three complementary legitimization procedures, which involve: (a) an intense dialogue to the "epistemological authority" of physics in the 1940's (Note 2), (b) the alliance to the speech about therapeutic potential in pathologies' treatment (yet in the 40's), (c) institutionalization of scientific policy and Big Science's pattern in the USA.

\subsection{The Dialogue with the Physics on "Atomic Age"}

The most evident of those is the intense communication of biology with "Big Science's" Physics in the 1950's, when the life sciences' agenda promoted a real exchange between the nuclear physics' tools in order to create macromolecules' models (mainly using X-Ray Crystallography).

Based on the works of Crick and Watson, the English (bio)physicists Max Perutz and John Kendrew used such tools and developed the first model of hemoglobin's molecular structure, at the Medical Research Council Unit for Molecular Biology in Cambridge, in 1958. Four years later, Crick, Perutz and Kendrew were awarded with a Nobel Prize. By this time, they were already established at one of the most modern labs of protein structures, sponsored by the Chemistry department of Cambridge University (de CHADAREVIA, 1994; PERUTZ apud STRASSER, 1987).

This contact with physics made possible the MB's institutionalization in a field already plenty of steady human and financial resources, especially in England and France of the 1950's. The prestige level of physics in the post-war period, allied to a change of pivot (also organizational) in scientific policy in the USA, allowed a reaffirmation of molecular biology as support to the Atomic Age statements.

Physics emerged as a symbol of scientific modernity. Its prestige was not restricted to the academic community. It held the promise of a new society based on technological innovation which would allow big advances on the quality of life standards. According to the historian of science Bruno Strasser, the association between MB and physics assumed, at least, three different potential meanings:

Firstly, molecular biologists, by emphasizing their reliance on techniques and instruments derived from physics - such as radioactive isotopes and electron microscopes - tried to acquire the epistemological authority associated with powerful physical instrumentation (Keller, 1990) (...) Secondly, the links between molecular biology and biophysics (...) played an important role in situating molecular biology in the post-war atomic energy debates. After Hiroshima and Nagasaki, research in biophysics was often considered desirable because it offered possibilities for transforming the public image of physical research and redeeming atomic energy from its association with the bombs (...) Thirdly, and perhaps even more significantly, high energy physicists had succeeded-a decade before molecular biologists - in establishing a close relationship with the state and thus in gaining unprecedented support for their research (...) (STRASSER, 2002, p. 530). 
In this regard, what stands greatly evident is that the social construction of $\mathrm{MB}$ as a knowledge area, in the second half of the $20^{\text {th }}$ century, is situated on an historical specificity of the Occident, and it already comes as a proposal to modern science in its role of society's transformation. This takes us to a second element concerning MB's construction: its association to the speech of applying biological research in medicine.

\subsection{Potential for Pathologies' Treatment and the Rockefeller Foundation (RF)}

The emerging of an agenda of research on Molecular Medicine - the diseases' study at the cellular structure level, with the development of genomic interventions, more than just an observation of the human being and its organs - is a reality connected to the works in the Molecular Biology's centers established in England and France. This is a fundamental movement of $\mathrm{MB}$, once it turns to compose the historical and institutional bases for medicine in the 1950's. A remarkable feature of this orientation process of MB to medical research involves two fundamental elements.

On the one hand, it is related to the expansion of the pharmaceutical industries' complex (especially after the manipulation of penicillin effects on human beings, by Howard Florey and Ernst Chain, at the Oxford University, in 1940) and its intensification in the 1950's. On the other hand, it is allied to the international sanitary project of some philanthropic institutions, focused on the support for research and technological development in health, with emphasis on the Rockefeller Foundation (RF) (ABIR-AM, 1982; FUERST, 1984), mainly oriented towards the enlargement of productive platform of medicines, vaccines and medical compounds for the under-developed world.

RF was the great pivot of technological spread on biomedicine in the $20^{\text {th }}$ century, investing on the creation of centers for professional training and human resources, hospitals and sanitary research centers (YOXEN, 1984). According to Abir-am, between 1932 and 1959, RF spent around US\$ 90 millions in programs of biological research around the world, and it contributed to "create" subjects about molecular biology in many countries (ABIR-AM, 1982). Among other aspects, RF was responsible for the set of the main structures and loads of scientific production in the area in the countries where the foundation was present. This process was more incisive in under-developed countries, which were still unprovided of a national system of science and technology directed towards research in the medical and life sciences areas.

However, which were the implications of this new set for the agenda of scientific production in MB? One of them was that the resources' mass applied in medical research was quickly incorporated in the molecular research's agenda, turning possible a great part of the progress towards "molecularization" on diseases' treatment, thanks to new technologies' development. Yet, this association is not unanimous: the Social Studies of Science magazine, in 1984, dedicated the $14^{\text {th }}$ edition of its publication almost entirely to attending the controversy of RF's role in MB's development in the $20^{\text {th }}$ century (Note 3 ).

According to Bartels, RF's support was crucial for the advances in studies about the structure and functioning of the gene, especially in the 1930's and 1940's. 
In the late 1940s, the National Institutes of Health (NIH) were taking over in the United States, while in Britain molecular biologists had to turn to the Medical Research Council (MRC) for support. At the same time, the Rockefeller Foundation chose to realign its funding strategy away from questions of gene structure and towards those of crop agriculture (idem, p.239).

The power relationships inside biology's scientific field started to change as long as the molecular aspect of investigations and new instruments for genetic analysis materializes itself. The influence of the emerging pharmaceutical industries' complex in the definition of the research on life sciences' agenda has begun to appear. RF played an important role in this scenario because it makes us question about the procedures employed by the social forces to direct technoscientific progress (and also about how do the generated artifacts reproduce the same game of power). To analyze its role (as well as the others philanthropic institutions' ones in the contemporary scientific agenda) is fundamental to our interpretation of how power and interests' relationships are inherent to scientific production.

\subsection{The "Modernizing" Speech of the "Big Science"}

The notion of "big Science" ("institutionalized research" age) is related to the emergence of a new state intervention standard and also to the organization of the scientific and technological policy in post-war period started in the USA. It was when the State started to define an agenda for the consolidation of a national system of S\&T, strongly anchored on scientific research as a tool for promotion of economic and social development in the modern world inspired on the report organized by Vannevar Bush, "Science: the endless frontier" (MOWERY, 1998).

The centralization of the research management on the State's "hands" could, thereby, reach meaningful levels in science production and in its application in the society development as a whole. This was the prevailing speech in the USA of the 1950's that has decisively influenced the pioneering and progress of researches on molecular biology, once given the degree of development on nuclear physics and precision technologies - both held by heavy investments in military research.

The research is no longer something fragmented on the society, and it turns to be the result of an institutional dynamics increasingly larger, more complex and diverse, founded on distinct instruments of R\&D activity's promotion. This process of deep institutionalization of the scientific research in the USA only gets deeper as the years go by.

This situation has made the national priorities' establishment really clear. The technologies' development was anchored on great resources' mobilization - which had been doubled between 1950 and 1962 (de SOLLA PRICE, 1963). The growth of the institutional framework generated for supporting research and technological development on that context had only reinforced, until the mid-70's, a legitimacy of the State as manager/funder agent of science and technology, in altogether articulation with universities.

All of these elements have had a particular impact in MB's research agenda, for a central reason: the systematization of a truly national policy (in the USA) in S\&T on the life sciences area, which allowed an expansion of funding towards knowing cellular structure and gene's 
functioning. From the specific life sciences' point of view, there was the creation of a national chain of research on health, with the reinforcement of the National Institutes of Health (NIH) (Note 4) - which would become the major public organ for fundraising to basic biomedical research in the USA (OSTHUS \& BENOS, 2006).

\section{Biomedicine, Biotechnology and the Emergence of ICTs}

The 1960's inaugurated a new practice in research on molecular biology, which has greatly reoriented the main data and information bases about DNA's structure. Among the aspects, the extensive standardization of the genetic research based on computing models prevailed on MB's agenda. This computer models' generation in genetics first appeared in the work coordinated by the researcher Margaret O. Dayhoff, entitled Atlas of Protein Sequence and Structure, in 1965 (DAYHOFF et al., 1965).

The work represents a remark in the load of knowledge's production about molecular biology in $20^{\text {th }}$ century, being noticed as the rise of sequence analysis assuming position as the characteristic strategy of the organization of research in the area (STRASSER, 2010).

\footnotetext{
Collecting, comparing, and computing protein or DNA sequences are among the most prevalent practices in contemporary biomedical research. They constitute a specific way of producing knowledge about the nature and the role of genes and proteins (...) In subsequent years under Dayhoff's leadership, the Atlas grew in size and popularity, becoming a common fixture in biomedical laboratories (...) In the historiography of the life sciences, the rise of sequence analysis has been tied to the development of the field of molecular evolution (Idem, p. 624).
}

An interesting aspect of this schedule of research in MB is related to its evolutionary nature. Often, the research's results advance from a cumulative process of knowledge, essentially anchored on a historical relationship. This has implications of great importance to the Sociology of Science's literature, especially in Thomas Kuhn's work Structure of Scientific Revolutions (KUHN, 1998). According to the work's line of reasoning, it is possible to observe that MB's evolution towards making computing models follows a historical path of evident transdisciplinary nature and rooted on the progress of information and communication technologies.

(...) the key practices of molecular evolution - collecting, comparing and computing sequences were already well established by 1962, having developed during the previous decade in three unrelated fields: biochemical research on protein function, theoretical studies of the genetic code, and attempts to apply digital computers to the life sciences (STRASSER, 2010, p. 624).

In that context, an intensification of the efforts of the global academic community towards the "standardization" of the computing models has been seen. There was the emerging of new research organization strategies by an intense database using, already containing a satisfactory precision degree for continuing the studies about gene's structure (KELLER, 2002).

This dynamics was understood as immersed into a new process that the contemporary Sociology of Health literature has been calling "Biomedicalization" (Note 5), which according to Adele Clarke (2003) is a complex system of knowledge accumulation in the 
biomedical sciences' area, whose main remark is the union of science and technology in a phenomenon known as biomedicine's technoscientifization.

The process of biomedicalization must be understood, on the one hand, from knowledge's accumulation in health area, and otherwise, by the main features of biomedicine since the end of the $20^{\text {th }}$ century. From medicine $\left(19^{\text {th }}\right.$ century) to biomedicalization (1980 until nowadays), Clarke (2010) draws attention to three important historical moments: (1) the medicine's appearance (1890-1945), moment of medicine's professionalization until the Second World War, period when the control of contagious diseases is highlighted; (2) from the Second World War to 1985, period nominated as medicalization, when the concern about chronicle diseases such as cancer is remarkable, and finally, (3) from1980 until present days, period of biomedicalization, in which the focus turns to be more in health itself than in disease.

A remarkable feature of MB in the period post 1980 is that its incursion in medicine became increasingly important and "strong". Thereby, there were an overflow of molecular researches and the mass creation of high science-based medical equipments and technologies. These researches, since the ending of the 1970's, have already became fundamental for continuing big research projects about the genetic nature of diseases. For Clarke, this was the paradigmatic moment of biomedicine's technoscientifization:

(...) many of the biomedical innovations (...) are situated in organizations that are themselves increasingly computer-dependent in heterogeneous ways that in turn are increasingly constitutive of those organizations. The application of computer technologies within multiple biomedical domains and their organizational infrastructures are thereby mutually constructed, creating new social forms for orchestrating and performing the full range of biomedically related work (CLARKE, 2003, pp 173).

What remains clear is that, from that moment on, the process of scientific evolution on MB can no more be disconnected from the intensive employment of technological and informational instruments. In the organization of this cognitive system, actors (human and not human) and distinct speeches of legitimization are allied, directing the whole production of posterior knowledge.

This interactive dynamics with the ICTs has given the legitimacy to MB for an expressive process of institutionalization in the last decades of the $20^{\text {th }}$ century. A renewal of its own foundations of scientific production became possible through a continuous transformation on the technological bases and by the formation of truly global research networks - greatly sponsored by R\&D departments and multinational companies.

As analyzed by Clarke (2003), an important aspect in the biomedicalization process is the transnationalization of knowledge, in other words, the dynamics of "how the knowledge travels". It travels as easily as we take a plane from São Paulo to Buenos Aires, with the advantage of original and copies never being identical, once the knowledge is always locally situated.

The knowledge's mundialization/globalization is a phenomenon present at the labs and it is a necessary factor for the construction of a field of knowledge that gets changed really quickly. 
The knowledge grows old as fast as new discoveries are realized, though, as Clarke says (2010), it is all about a cumulative knowledge.

The TIC's and the process of biomedicine's technoscientifization have made possible the knowledge's dissemination through information networks, as likewise allowed an approach between the knowledge producing in central and peripheral countries, maintaining, nevertheless, the same power associations between center and periphery, metropolis and colony. Knowledge also promotes, thus, a reproduction of colonial relationships, which, associated to the biological speech, gains legitimacy.

\section{Scientific Convergence and Social Meanings of the Sequencing Practice}

This dialogue opened not only an international "race" to complete human genome sequencing: it also represented a material and spatial relocation of the infrastructure of high technology biomedical research - "the rupture and relocation of material, social and national boundary demarcations" (LOCK 2007; LÖWY, I \& GAUDILLIÈRE, Jean-Paul, 2008).

The emerging of information technologies (allied to a basis' enlargement of the scientific and technological policy in developed countries) has supported the articulation of a resetting in the platforms of knowledge about molecular life at global level. This has changed the load of scientific production in the area and then, an exponential rising in the number of researches oriented to human genome sequencing has been seen.

The paths of legitimization of the occidental science, though, are not total-global phenomena, and the knowledge progress is involved in a co-evolutionary process of interaction among the meanings that science has to each society. What exemplifies this transnational effort is the case of International Human Genome Sequencing Consortium (HGSC). Started in 1997, it has involved 20 groups of research in the USA, England, Japan, France, Germany and China (Note 6).

From the perspective of the articulation of the load of scientific production about genome, its possibility came from two primary conceptions. The first one is about the ability to coordinate global visions over genetics, which would assist some important advances on biomedical research. According to the second one, once the problems were mutual (and the fragments' collect of sequences was a long hard process), the consortium would stimulate an effort to fasten results with the mutual employment of the infrastructure set in universities, labs and international research centers (NATURE, 2001).

Concerning HGSC, the investments made by public and private institutions also guaranteed the project's viability, and simultaneously, an intense demand was created by some of the involved scientists for techniques, equipments, softwares and procedures that would lead to the automation of part of the research activities.

Even authors with distinct visions on the Human Genome Project (HGP) as Watson (2005) and Keller (2002), agree with the fact that were crucial both the support of different groups from the American society and the financial support and market created around biotechnology. Over the first years, the sequencing occurred by means of manual techniques 
and the scientific community signed for the non-fulfillment of sequencing goals. Some scientists, noticing the demand for more effective equipments, created enterprises along the project development. That was the case of the scientists Mike Hunkapiller and J. Craig Venter who have founded, in 1998, the Celera Genomics (OSADA, 2007; Pereira, 2005).

What has been observed in this stage of the research in MB is its high degree of standardization and automation. In this new load, the molecular biologist needs to dominate the knowledge in Biology and in computing in order to produce progress in the area (JORDAN, 1998).

\section{Conclusion}

There are, thus, three elements about the social meanings of HGSC: (1) the rising of transdisciplinary knowledge about cellular life and the definitive inclusion of studies concerning genome as a vector of medicine's development; (2) the streamlining of molecular investigation activities in the lab and the creation of technoscientific platforms based on free international traffic database; and (3) an effort for standardizing the local loads of biological knowledge production at global level, founded on a globalization of medical technologies created in the developed world, reproducing colonial relationships (LOCK, 2007) expressed in equipments, cell lineages and cultures, methodologies of genetic sequencing, etc.

It remains really clear that the scientific community has the "control" of technoscientific progress as a fundamental element in its historical line of legitimization. Among other aspects, the technical ownership reproduces power relationships and imposes values, generating an expertise that (each day more) often takes part on the procedures of definition of global policies' agenda. An important question that stands answerless is if those science's directions redefine the epistemological bases under which they evolve. It is like questioning: does the deepening of interdisciplinary research in MB represent the collapse of the conventional biology for handling the empirical problems of cellular life or is it an historical phenomenon of the power game, carried in the own nature of the technological artifact?

\section{Acknowledgements}

This work was made possible through funding support from the São Paulo Research Foundation, FAPESP, for the project: "Platforms of Scientific Knowledge reproduction in Oncogenomics" (Grant n. 11/14894-8) and "Reconfiguring Biomedical Scientific Activity in 21th century: implications for Cancer Research agenda" (Grant n. 12/08001-3). We would like to acknowledge the Department of Science and Technology Policy, from State University of Campinas, and the Institute for the Study of Science and Technology at University of Edinburgh, UK, for the contribution to the projects.

\section{References}

ABIR-AM. (1982). The Discourse of Physical Power and Biological Knowledge in the 1930s: A Reappraisal of the Rockefeller Foundation's "Policy" in Molecular Biology. Social Studies of Science, 12, 341-82. https://doi.org/10.1177/030631282012003001

Yoxen, E. J., \& Abir-Am, P. (1984). Scepticism about the Centrality of Technology Transfer 
in the Rockefeller Foundation Programme in Molecular Biology. Social Studies of Science, 14, 248-52. https://doi.org/10.1177/030631284014002006

Abir-Am, P. (1993). From multidisciplinary collaboration to transnational objectivity: International space as constitutive of molecular biology, 1930-1970. In E. Crawford, T. Shinn, \& S. So rlin (Eds.), Denationalizing science-The contexts of international scientific practice (pp. 153-186). Dordrecht: Kluwer Academic Publishers.

Strasser, B. J. (2010). Collecting, Comparing, and Computing Sequences: The Making of Margaret O. Dayhoff's Atlas of Protein Sequence and Structure, 1954-1965. Journal of the History of Biology, Winter, 43(4), 623-60.

AYUANG, S. (n.d.). Scientific convergence in the birth of molecular biology. Retrieved June 12, 2011, from http://www.creatingtechnology.org/Auyang

BBC BRASIL. (n.d.). "Pai de Dolly" abandona clonagem de embriões. Retrieved July 27, 2011, from http://www.bbc.co.uk/portuguese/reporterbbc/story/2007/11/071117_clonagem_cg.shtml

Bijker, W., \& Pinch, T. (1990). The Social construction of Technological systems. Cambridge, MIT Press.

Bijker, W. (1995). Of Bicycles, Bakelites, and Bulbs. Toward a Theory of Sociotechnical Change. Massachusetts, MIT Press.

Callon, M. (1987). "Society in the Making: The Study of Technology as a Tool for Sociological Analysis". In: BIJKER, W. et al. Social Construction of Technological Systems. Cambridge: Cambridge University Press.

Clarke, A. et al. (2003). Biomedicalization: Technoscientific Transformations of Health, Illness, and U.S. Biomedicine. American Sociological Review, 68, April, 2003, 161-194. https://doi.org/10.2307/1519765

Clarke, A., Shim, J., Mamo, L., Fosket, J., \& Fishman, J. (2010). Biomedicalization: Technoscience and Transformations of Health and Illness in the U.S. Durham, NC: Duke University Press.

COHEN, Eric. (2004). The Bioethics Agenda and the Bush Second Term. New Atlantis Journal of Technology and Society. Retrieved June 26, 2011, from http://www.thenewatlantis.com/publications/the-bioethics-agenda-and-the-bush-secondterm

DAYHOFF, Margaret O, ECK, Richard V, CHANG, Marie A. and SOCHARD, Minnie R. Atlas of Protein Sequence and Structure. Silver Spring: National Biomedical Research Foundation, 1965.

de Chadarevian, S., \& Kamminga, H. (1998). Molecularizing biology and medicine: New practices and alliances 1910s-1970s. Amsterdam: Harwood Academic Publishers. https://doi.org/10.4324/9780203304235

de Chadarevian, S. (1996). Sequences, conformation, information: Biochemists and 
molecular biologists in the 1950s. Journal of the History of Biology, 29, 361-386. https://doi.org/10.1007/BF00127380

de Solla Price, D. (1963). Little Science, Big Science. New York: Columbia University Press.

Fagot-Largeault, A. (2004). Embriões, células-tronco e terapias celulares: questões filosóficas e antropológicas. Estudos Avançados, 18(51), 227-245. https://doi.org/10.1590/S0103-40142004000200015

Fuerst, J. A. (1984). The Definition of Molecular Biology and the Definition of Policy: The Role of the Rockefeller Foundation's Policy for Molecular Biology. Social Studies of Science, 14, 225-237. https://doi.org/10.1177/030631284014002003

Keller, E. F. (1990). Physics and the emergence of molecular biology: A History of cognitive and political synergy. Journal of the History of Biology, 23, 389-409. https://doi.org/10.1007/BF00136376

Keller, E. F. (2002). The century of the gene. Harvard University Press, Cambridge.

KUHN, Thomas S. (1998). A estrutura das revoluções científicas. $5^{a}$ ed. São Paulo: Perspectiva.

Latour, B. (1992). Where are the missing masses? The sociology of a few mundane artifacts. In: W. BIJKER and J. LAW (orgs.) Shaping Technology/Building Society. Cambridge, Mass: MIT Press.

LOCK, Margaret. Biomedical Technologies, Cultural Horizons, and Contested Boundaries.", pp. 875-900 in The Handbook of Science and Technology Studies, (eds.) HACKETT, E J. AMSTERDAMSKA, O; LYNCH, M. \& WAJCMAN, J. Cambridge, MA: MIT Press, 2007.

Löwy, I., \& GAUDILLIÈRE, Jean-Paul. (2008). Localizing the Global: Testing for Hereditary Risks of Breast Cancer. Science, Technology \& Human Values. https://doi.org/10.1177/0162243907306855

Mahoney, J. (2000). Path dependence in historical sociology. Theory and Society, 29(4), 507-48. https://doi.org/10.1023/A:1007113830879

MOWERY, D. (1998). The changing structure of the U. S. national innovation system: implications for international conflict and cooperation in R\&D policy. Research Policy, 27, 639-654. https://doi.org/10.1016/S0048-7333(98)00060-2

NATURE. (2001). Initial Sequencing and analysis of human genome. Nature, 409, February(15), 86-921.

NIH STEM CELL INFORMATION. (2011). NIH Stem Cell Research Funding, FY 2002-2010. The National Institutes of Health resource for stem cell research. Retrieved June 20, 2011, from http://stemcells.nih.gov/research/funding/funding.htm

North, D. (1990). Institutions, institutional change and economic performance. Cambridge: Cambridge University Press. https://doi.org/10.1017/CBO9780511808678 
Osthus, R., \& Benos, D. (2006). Making a Case for NIH Funding: How Cures Are Built on Decades of Research. The Physiologist, 49, 313-21.

Pierson, P. (2000). Increasing returns, path dependence and the study of politics. The American Political Science Review, 94(2), 251-67. https://doi.org/10.2307/2586011

PINCH, T, BIJKER, W. The social construction of facts and artifacts: or how the sociology of Science and the Sociology of Technology might benefit each other. In: 13 STEM CELLS NEWS. Latest Stem Cells News. Disponível em: <http://www.stem-cellsnews.com/1/>. Acesso em 20 de Junho de 2011.

STRASSER, B. (2002). Institutionalizing molecular biology in post-war Europe: a comparative study. Studies in History and Philosophy of Biological \& Biomedical Sciences, 33, 515-546. https://doi.org/10.1016/S1369-8486(02)00016-X

Thomson, J. (1998). Embryonic Stem Cell Lines Derived from Human Blastocysts Science, 282(5391), 1145-1147.

VELHO, L. Conceitos de Ciência e a Política Científica, Tecnológica e de Inovação. Sociologias, Porto Alegre, ano 13, no 26, jan./abr. 2011, p. 128-153.

WAJCMAN, Judy. (eds.) The Handbook of Science and Technology Studies, Cambridge, MA: MIT Press (3a ed).

Winner, L. "Do Artifacts have Politics?" In: WINNER, L. 1986. "The Whale and the Reactor: A Search for Limits in an Age of High Technology". Chicago: The University of Chicago Press. p. 19-39.

Yoxen, E. J. (1982) Giving Life a New Meaning: The Rise of the Molecular Biology Establishment. In N. Elias, H. Martins \& R. Whitley (eds), Scientific Establishments and Hierarchies, Sociology of the Sciences Yearbook, 6, 123-43. https://doi.org/10.1007/978-94-009-7729-7_5

\section{Notes}

Note 1. “(...) molecular biology arose from the convergence of work by geneticists, physicists, and structural chemists on a common problem: the structure and function of the gene (...) The field of molecular biology studies macromolecules and the macromolecular mechanisms found in living things, such as the molecular nature of the gene and its mechanisms of gene replication, mutation, and expression (...) molecular biology is a relatively young discipline, originating in the 1930s and 1940s, and becoming institutionalized in the 1950s and 1960s(...)" (STANFORD ENCYCLOPEDIA OF PHILOSOPHY, Molecular Biology, 2009). Yet according to Auyang "Molecular biology, then, is the study of how DNA, RNA, and protein are interrelated," summarized David Baltimore in his forward to Nobel Lectures in Molecular Biology. In this sense, "molecular biology" refers to a focused science" (AYUANG, 2011). 


\section{Macrothink}

Note 2. Until 1933, the scientific community wasn't convinced yet about the real existence of the gene (KELLER, 2002; 14)

Note 3. The articles of this volume are described in the bibliography, and they were used as a research material throughout this paper.

Note 4. Nowadays, the NIH is constituted by 27 different institutes, each one with its own budget program. It involves great part of research on health in the USA. Only a smaller part of NIH's budget, nowadays, is invested on basic biomedical science, which is a more difficult defending area than the more applied medical research, although the boundaries between basic and applied research are really fluent, particularly on medicine (MALNIC, 2007). The NIH is considered a centre of excellence on research because it concentrates a lot of highly-trained professionals, besides a relative budget protection even if compared to high level American universities.

Note 5. About biomedicalization's perspective, Clarke points to distinct "interactive-key processes": (1) technoscientific complex, (2) new perspective: focus on health, risk and watch, (3) biomedicine's "technoscienticism", (4) knowledge logistics, and (5) transformation of body and identities. (CLARKE, 2010, p.163).

Note 6. "The idea of sequencing the entire human genome was first proposed in discussions at scientific meetings organized by the US Department of Energy and others from 1984 to 1986 (...) In addition, the Human Genome Organization (HUGO) was founded to provide a forum for international coordination of genomic research (...) Several books provide a more comprehensive discussion of the genesis of the Human Genome Project” (NATURE, 2001).

\section{Copyright Disclaimer}

Copyright for this article is retained by the author(s), with first publication rights granted to the journal.

This is an open-access article distributed under the terms and conditions of the Creative Commons Attribution license (http://creativecommons.org/licenses/by/3.0/). 